\title{
John Goudie: A Scottish Master Shipbuilder in Canada in the Early Nineteenth Century
}

\section{Eileen Marcil}

Né en Écosse en 1775, John Goudie a été constructeur de navires éminent à Québec depuis 1800 jusqu'à sa mort en 1824. S'appuyant en grande mesure sur des documents d'archives tels les nombreux contrats qui le mettaient en cause ainsi que sur des documents familiaux, le présent article biographique décrit la vie d'un entrepreneur en transport maritime prospère alors qu'il bénéficiait des nouvelles possibilités liées au transport maritime de son époque. Cet article a d'abord été présenté au congrès de la Société canadienne pour la recherche nautique à Kingston, en Ontario, en $1984 .^{1}$

In 1883, James Goudie, the marine architect for the paddle steamer Royal William, who was then seventy-three years old, looked back over his father's career and deplored the fact that John Goudie had not been given the place he deserved in Canadian history. ${ }^{2}$ Since then, a century has passed, and John Goudie remains relatively unknown. Fortunately, the richness of our archives allows us to make amends.

Notaries' files at the Quebec National Archives (ANQ) contain over 250 deeds to which John Goudie was one of the parties. They include contracts for the construction, repair or sale of a vessel, engagements of tradesmen or apprentices, property sales or leases, financial agreements, and even the inventory of Goudie's

\footnotetext{
${ }^{1}$ This is the text, with updated footnotes, of a paper first presented at the Canadian Nautical Research Society conference in Kingston, Ontario, in 1984. It was then distributed by CNRS in a booklet titled Canada's Atlantic Connection. Subsequently the author used it as the basis for her entry about John Goudie in the Dictionary of Canadian Biography.

${ }^{2}$ Letter to the Quebec Morning Chronicle, 24 January 1883, (James Goudie letter).
}

The Northern Mariner / Le marin du nord, XXIX, No. 3 (Fall 2019), 255-268 


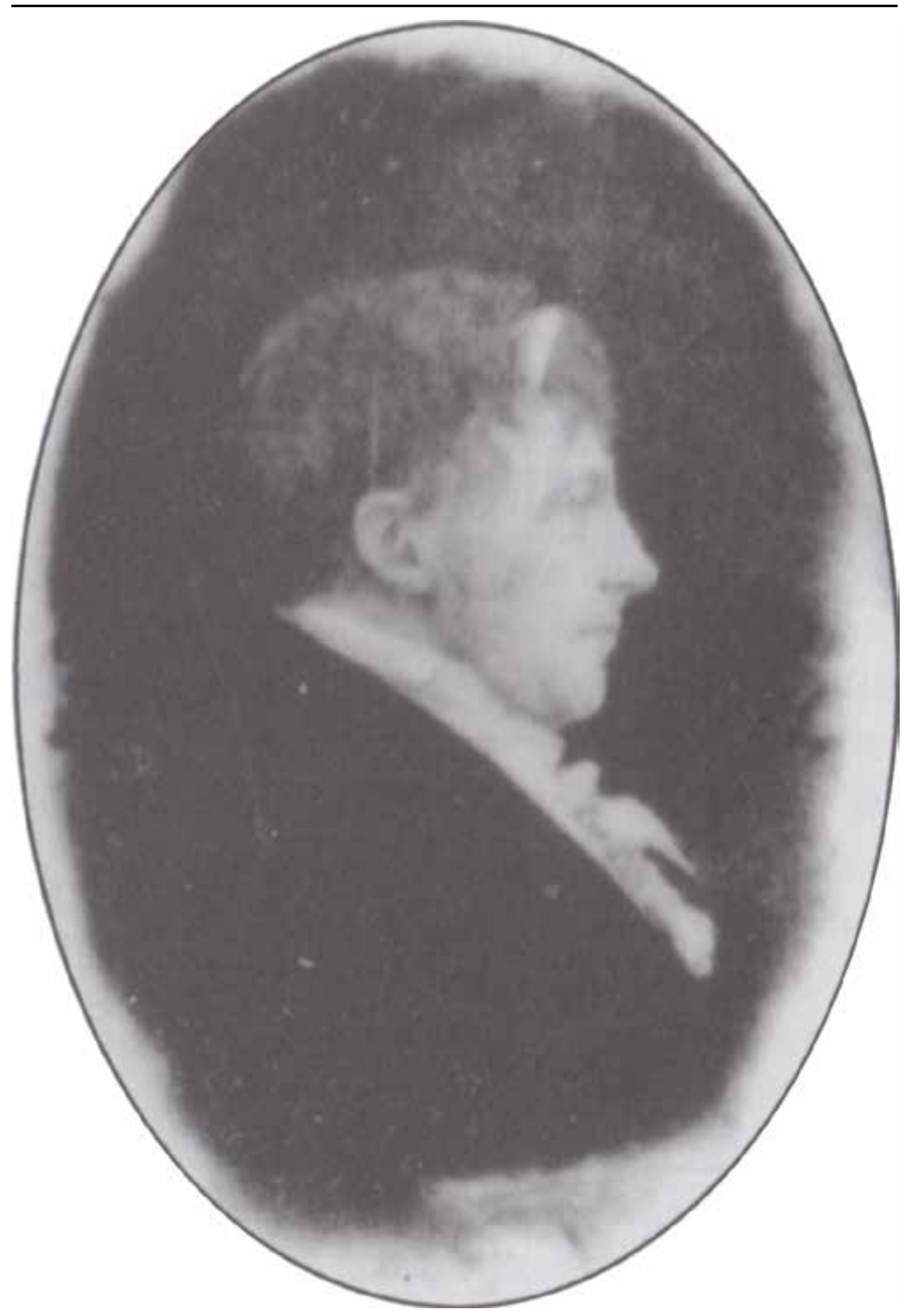

Miniature by Garrit Schipper. Photo courtesy Peggy Bolenbaugh 
property taken after his death. They formed an important part of the original research for this paper. The registers of the Port of Quebec, on microfilm at the Library and Archives, Canada, (LAC), provided the details of all vessels registered in Goudie's name, though some that were built but not registered by him may have remained unidentified, as the name of the builder does not appear on all registries. Information concerning Goudie's war time activities was taken from the military C-series at the LAC, and also from Admiralty papers at The National Archives, Kew, England. The registers of St Andrew's Church, Quebec, and Quebec newspapers served as well.

A second line of research involved locating and contacting John Goudie's descendants, several of whom kindly sent a copy of James Goudie's letter to the Quebec Morning Chronicle, in which he recounted his father's career, and of which I was at the time unaware. The family also supplied photographs of a portrait of John Goudie and of James Goudie. In addition, Mr. Ainslie Goudie graciously donated an original plan of the 56-gun Prince Regent to the LAC. I discovered with sadness, however, that had the research been done a few years earlier, a number of documents belonging to John Goudie, including other plans, and letters from Goudie's friend, the American shipbuilder Henry Eckford, might also have been uncovered.

James Goudie's letter has been most useful in that it has shown that the documents in the sources described above do indeed cover the main events in his life, and in some cases, the letter has added extra details. However, even family sources have not been able to provide any information about John Goudie's childhood, apart from supplying his date and place of birth, 15 September 1775 at Ayrshire, Scotland, and we do not know for certain whether he served his apprenticeship in Scotland or in Quebec, as the various “copies" of James' letter are contradictory. Thus, this account of Goudie's life begins in 1800, at which time he was twentyfive years old. He had probably served his time in Scotland and come to Quebec in $1795,{ }^{3}$ and he appears to have been working in Detroit in $1796 .{ }^{4}$ By 1800 , however, he was back in Quebec, had established himself as a shipbuilder, and had a 400 ton ship on the stocks. ${ }^{5}$

Thus he began a career unlike that of any other Quebec shipbuilder, meeting a very different challenge in each of three consecutive periods of his life. In the first, which lasted until the outbreak of the War of 1812, he devoted his energies to building up his shipyard, and was actively engaged in shipowning, as well as shipbuilding, salvage and repair. In the second, the war years, he became a naval contractor and built warships on both Lake Ontario and Lake Champlain. The largest of these equalled Nelson's Victory in size. In the third, the post-war years, the market for new tonnage had subsided, and though he carried on his former

\footnotetext{
3 Family sources.

${ }^{4}$ Library and Archives Canada (LAC), C series, vol 723, 43.

5 Bibliothèque et Archives Nationales du Québec (ANQ), gr J. Voyer, 27 October 1800.
} 
shipyard activities, his overriding interest lay in the applications of steam power, both ashore and afloat.

It was on the south bank of the St Charles River, in the suburb of St Roch that Goudie set up his shipyard. Like John Munn, his countryman and neighbour to the south-east, he gradually assembled parcels of beach property as the opportunity arose. By 1812, his land on the waterfront stretched from the north-east corner of St Roch to Dorchester Bridge, and in 1820, he pushed its western boundary back another 350 ' beyond the bridge, along Prince Edward Street, ${ }^{6}$ or, as the Curé Signay, and perhaps the locals called it, la rue des chantiers Goudie. ${ }^{7}$

From 1800 to 1812 , during his most prolific period of merchant sailing ship construction, Goudie built seventeen fully-rigged ships, two brigantines and five schooners of 100 to 554 tons, and three smaller craft. Eleven of the ships measured what was then considered a very respectable 400 tons or more. Through these years, his output more than doubled from an annual average of 400 tons during the first six years to 900 tons during the last six, representing 24 and 26 percent respectively of the total output of the Quebec City area. The large ships were built for timber or general merchants, such as Henry Usborne of London, or Rogerson, Hunter \& Company of Greenock, who, as was customary at the time in British North America, provided the funds to meet wages during construction, and found such items as bar iron, iron and copper bolts, ironwork for the tops and caps, the graving and glaziers' work, the joiner's work for the cabin, and sometimes the pump and blockmakers' work also. The vessels were built of oak, with extra stanchions stiffening the decks to support the weight of their armament of sometimes as many as twenty guns. ${ }^{8}$

The smaller vessels, however, were generally built for local owners, including Goudie himself, ${ }^{9}$ though even they were usually sold in Britain within a few years. ${ }^{10}$ Two notable exceptions were the small schooners ordered from him by Trinity House in $1806{ }^{11}$ and by the quarter master general in $1809,{ }^{12}$ which indicate that he was already at that time on favourable terms with both civilian and army authorities. He was, in fact, accepted in 1806 by Trinity House, as surety for the Master Mason Edward Cannon, who contracted with them to build a lighthouse on Green Island. ${ }^{13}$

These were busy and profitable years for Quebec shipbuilders. As Quebec's

\footnotetext{
6 ANQ, gr J. Belanger, 24 June and 31 October 1808, 24 February 1812 and 28 April 1820.

7 Recensement de la Ville de Quebec, 1818.

8 Information from Port of Quebec registers and various notarial contracts, as analysed for Eileen Reid Marcil "Shipbuilding at Quebec 1763-1893: The Square Rigger Trade" (unpublished PhD thesis, Laval University, 1987).

9 ANQ, gr J. Voyer, 14 August 1801; Port of Quebec Registry 16/1802.

${ }_{10}$ Port of Quebec registers.

11 ANQ, gr T. Lee, 18 April 1806.

12 ANQ, gr J. Belanger, 15 April 1809.

13 ANQ, gr John Jones, 21 June 1806.
} 
great timber trade got under way and the need for additional tonnage increased, prices rose from $£ 7$ per ton in $1805^{14}$ to as much as $£ 12$ or $£ 14$ in $1810 .{ }^{15}$ Moreover, the volume of repair and maintenance work requiring shipyard attention rose steadily as more and more vessels called at Quebec. In addition, the increasingly heavier traffic on the river, aggravated by the shortage of navigational aids, resulted in a greater number of stranded vessels available for salvage, and prizes condemned by the Admiralty Courts, often in need of repair, provided further business opportunities. ${ }^{16}$

We have no way of knowing how much of this work was undertaken by Goudie, but sufficient information exists to show that he was involved in all types of salvage and repairs. For instance, in a notarial contract of 1805, he agreed to repair the 174 ton brigantine Recovery belonging to Aylwin, Harkness \& Company, for the sum of $£ 800 .{ }^{17}$ and by another deed of 1809 , he bought the 163 ton snow Maria, ${ }^{18}$ a prize, for $£ 400$, re-selling her for $£ 1,600$ after repairs. ${ }^{19}$ Among the many wrecks bought by him, was the 330 ton snow Amphitrite, which was already twenty-three years old when he bought her in 1813. On her new register, it was noted that she had been "thoroughly repaired." 20

The outlay required to purchase and repair most prizes or wrecks, or to build a schooner or other small craft beside a larger vessel, was relatively small. Wrecks, for instance, were frequently knocked down for a pound or two per ton. ${ }^{21}$ Goudie could thus afford to repair and register such vessels, either in his own name or in joint ownership with others, and to operate them for at least one voyage before selling them. He would generally advertise them for sale or charter, ${ }^{22}$ and if they remained unsold and the cargo space was not all taken up, he would complete it with a cargo of lumber, ashes, and/or other commodities to be sold on his, or his and his partners' behalf. ${ }^{23} \mathrm{He}$ built up a network of agents and traded with the West Indies, Newfoundland, Labrador, as well as British ports, sometimes having to reverse things and charter the necessary shipping from another party to do so. ${ }^{24}$ In this way, Goudie built up a considerable shipbuilding and shipping business, which was referred to by his son James in later years as his "extensive shipbuilding

14 ANQ, gr J. Jones, 15 November 1805.

15 ANQ, gr J. Belanger, 19 October 1810. In 1813, Goudie sold the ship Goudies, 361 tons, built by him the previous year, for $£ 7,700$ or $£ 21.6 .8$ per ton. ANQ, gr J. Belanger, 1 July 1813 .

16 Port of Quebec registers, 1800 et seq.

17 ANQ, gr J. Jones, 15 December 1805.

18 ANQ, gr J. Voyer, 31 January 1809.

19 ANQ, gr J. Belanger, 11 September 1809.

${ }^{20}$ Port of Quebec Registry 32/1814.

21 ANQ, gr J. Belanger, 15 November 1813, L. McPherson, 6 June 1818.

22 Quebec Gazette, 1 June 1803.

23 ANQ, gr A. Campbell, 3 July 1810.

24 ANQ, gr J. Belanger, 4 August 1816. 


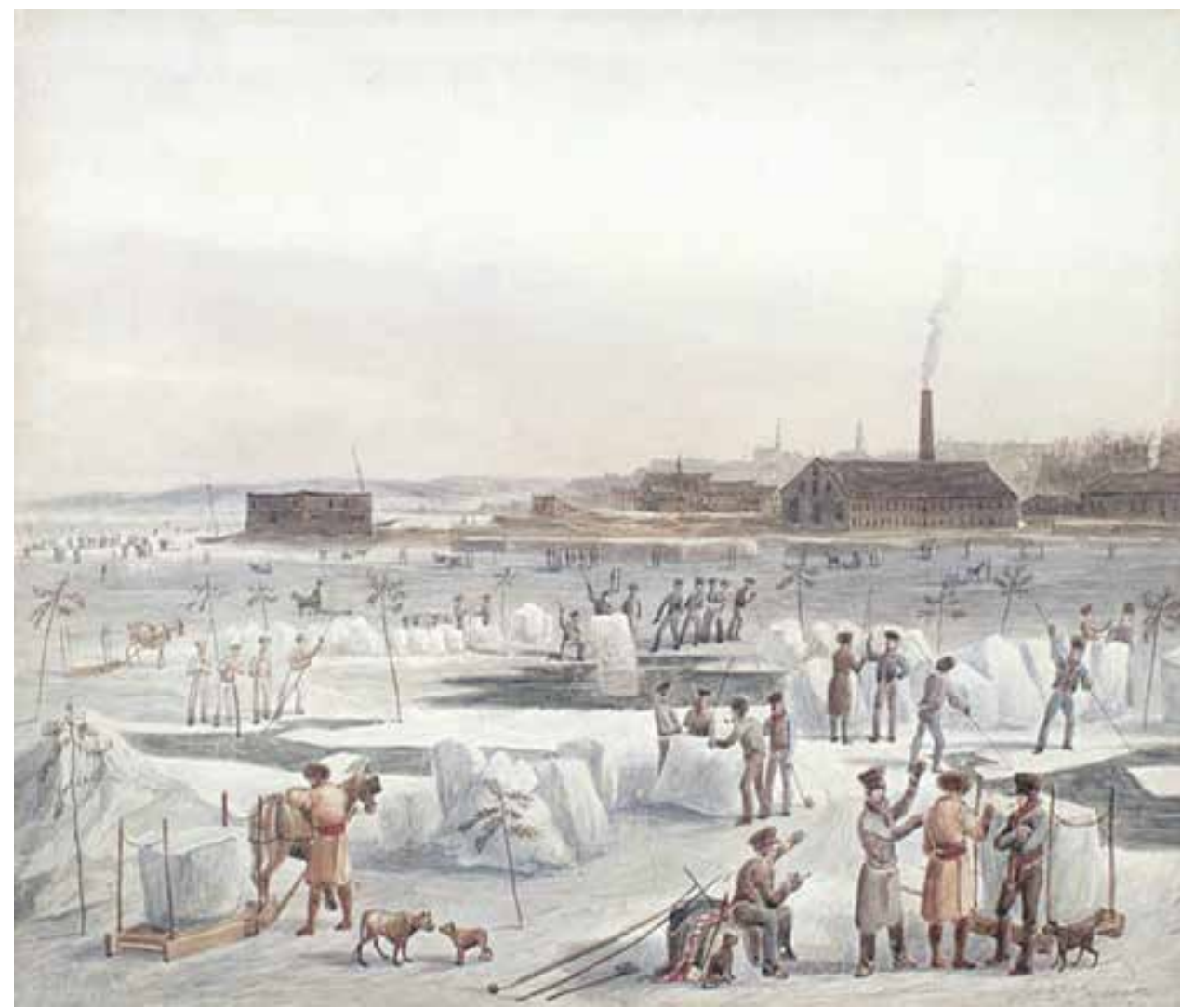

James P. Cockburn's watercolour of cutting ice in the St. Charles River. In the background is John Goudie's sawmill beside his shipyard, and to the left, John Munn's mould loft with a steeple. (Library and Archives Canada, C 150353)

operations." 25

There are no records indicating the size and composition of Goudie's workforce at any time, no hint of the number of permanent employees, the amount of work contracted out, nor the number of day labourers. Not only have no shipyard journals survived, but notarial files yield surprisingly few contracts between Goudie and his workers.

There is an occasional contract with a carpenter, a blacksmith or a pair of sawyers, engaged for a one, or on one occasion a two, year term. ${ }^{26}$ There is also a sub-contract for the carpentry and another for the ironwork of one small vessel as well as a few planking and caulking contracts, in 1810 and 1811 and an advertisement for tenders to build two ships. ${ }^{27}$ But these are of course in no way

${ }^{25}$ Quebec Morning Chronicle, letter of 24 January 1883.

26 ANQ, gr J. Belanger, 18 December 1806, 19 January 1808 and 5 November 1810.

27 ANQ, gr J. Belanger, 17 November 1810 and 5 June 1811; Quebec Gazette, 21 September 1818. 
representative of the complete picture. The same notaries' files, however, are far from barren in regard to apprenticeship indentures. At least thirty-nine of these, made between 1802 and 1820 have been found, of which no fewer than thirty date from the eleven year period, 1802 to $1812,{ }^{28}$ when the shipbuilding industry was mushrooming and shipwrights and other skilled workers were in heavy demand. Though this shortage was for the most part solved by having shipwrights and blacksmiths, etc. sent out from Britain, ${ }^{29}$ training a number of local youths over and above those trained in the traditional apprenticeship system, and thus enabling them to earn their living as skilled tradesmen, rather than remain in the ranks of the “day labourers," was far more acceptable to Quebeckers.

Most of the apprentices served a three-year term, living at home and receiving $£ 25$ to $£ 30$ per year, instead of being boarded and kept by their master, and were then qualified to earn a carpenter's wages ${ }^{30}$ It seems likely, that this training programme was undertaken with the same objective as the apprentice training program set up by Talon in the first Royal Dockyard at Quebec, more than a century earlier.

Goudie was, perhaps, the only shipbuilder to attempt to set up a rope-walk in Quebec. A four-year lease signed in November of 1809, for a fifteen-foot wide strip of land forming part of the footpath to the General Hospital, which was to serve for the rope walk also, and the engagement contracts of two rope-makers made three months later, are the only reference to it that have come to light. ${ }^{31} \mathrm{How}$ long the walk lasted and how successful it was, is therefore a matter of conjecture, along with all the other questions we may ask ourselves about the organization of the shipyard labour.

The first indications of Goudie's interest in setting up a sawmill appear in documents of 1810, regarding his purchase of land at Montmorency Falls, in partnership with the merchant Henry Black, ${ }^{32}$ followed a short while later by an agreement between the partners and the millwright Zimri Winchell, of Plattsburg. ${ }^{33}$ Winchell was to put a canal through the rock from the top of the Falls to convey the water to operate the mill, to construct the mill and to set up three sets of gears including one to draw the timber into the mill. In addition, he was to build a dwelling house and smithy. The contract was to be completed within ten months, but was cancelled for reasons that are not stated in the résiliation the following May. ${ }^{34}$ A settlement was made for the work that had been done. In October Goudie bought out his partner, who appears to have financed the project, for $£ 2,583$, the

\footnotetext{
28 Mostly in the records of the notary Jean Belanger.

29 LAC, MG 24, F3, correspondence 12 July, 21 December 1800.

30 ANQ, gr J. Belanger, 10 June 1805 and 5 June 1808.

31 Ibid., 29 November 1809 and 14 February 1810(2).

32 Ibid., 22 October 1811.

33 Ibid., 25 February 1811.

34 Ibid., 4 May 1811.
} 
amount of his cash equity, ${ }^{35}$ but then seven weeks later, Goudie in turn sold the entire project as it stood "with buildings, finished and unfinished and materials" to Peter Patterson and Henry Usborne, for $£ 3,000 .^{36}$ Were technical or financial problems responsible for Goudie giving up the project, or was he perhaps already dreaming of building a steam sawmill at his shipyard?

Although war with the United States had been widely apprehended for a number of years, when the Americans did strike, the Canadian naval force on the lakes, until then little more than an army transport service operating under the title the Provincial Marine,${ }^{37}$ had a new and vital role to play in the defence of the country. Sir George Prevost, commander-in-chief of British North America, immediately asked for and obtained permission to proceed with an emergency shipbuilding programme, subsequently giving orders for a frigate to be laid down at each of the three dockyards at Amherstburg, Kingston and York. ${ }^{38}$ Meanwhile, arrangements made for the building and operation of the fleet to be taken over by the British navy, went into effect in May 1813. ${ }^{39}$ York had fallen to the Americans a month earlier, the frigate Sir Isaac Brock having been burnt on the stocks to prevent her from enhancing their fleet, ${ }^{40}$ and the brig Detroit, launched at Amherstburg in July, was also lost to the Americans together with the rest of the British establishment on Lake Erie, when Amherstburg capitulated two months later. ${ }^{41}$ On the Great Lakes, only the dockyard at Kingston remained in British hands.

Under the direction of the master shipbuilder of the dockyard, George Plunknett, the twenty-three--gun frigate Wolfe had been launched there in April, ${ }^{42}$ and the smaller fourteen-gun brig Lord Melville was under construction. ${ }^{43}$ In June, in answer to an urgent request from Sir George Prevost, who felt that a greater effort was required at that most critical period, ${ }^{44}$ Goudie left for Kingston with a first contingent of one hundred workers recruited in Quebec..$^{45}$ Once there, he set them to fitting out all available suitable merchantmen for service. ${ }^{46} \mathrm{He}$ also laid down the fifty-six-gun frigate Prince Regent, ${ }^{47}$ which was draughted by Patrick

${ }^{35}$ Ibid., 22 October 1811.

${ }^{36}$ Ibid., 12 December 1811.

${ }^{37}$ W.A.B. Douglas, Gunfire on the Lakes (Otawa: National Museum of Man - Canadian War Museum, 1977), 4.

${ }^{38}$ Ibid., 6.

${ }^{39}$ R.A. Preston, “The Fate of Kingston's Warships," Transactions of the Kingston Historical Society

1: 5 (1974).

${ }^{40}$ LAC, C series, vol 729, 183-6.

${ }^{41}$ Parks Canada, Shipbuilding at Fort Amherstburg, 1796-1813, LAC, C series, vol 731, 115.

42 LAC, C series, vol 729, 169; The National Archives (TNA), Kew, ADM 106, Vol 1,997, 14

October 1814.

${ }^{43}$ Ibid.

${ }^{44}$ LAC, C series, vol 739, 116-8.

${ }^{45}$ ANQ, gr J. Belanger, 22 June 1813; Quebec Mercury, 22 June 1813, brought to my attention by A.J.H. Richardson.

${ }^{46}$ James Goudie letter.

${ }^{47}$ Ibid. 
Fleming, one of his foremen shipbuilders. ${ }^{48}$ Master Shipbuilder George Record had contracted to build the smaller thirty-six-gun frigate Princess Charlotte. ${ }^{49}$ However Record resigned in October, ${ }^{50}$ and the work was taken over by Goudie. Both vessels were launched on 14 April 1814. ${ }^{11}$ By then, Goudie had contracted to build another vessel, which was to be far larger than any hitherto built on the lakes. ${ }^{52}$ HMS St Lawrence would mount 112 guns on three decks, and have a 171' keel and a 53' beam. ${ }^{53}$ She was draughted by Master Shipbuilder William Bell, who after serving fourteen years at Amherstburg Dockyard, had taken charge at Kingston on George Record's withdrawal. ${ }^{54}$ The St Lawrence was launched on 10 September 1814 , to a royal salute from the batteries. ${ }^{55}$ She measured 2,300 tons. ${ }^{56}$

The successful launching of these vessels was a great triumph for Goudie. Getting large numbers of workers to Kingston and keeping them there was in itself a challenge. The steamboat $\operatorname{trip}^{57}$ to Montreal presented no difficulty, but from Montreal the journey was continued by batteaux, which had to be towed by the men themselves over the numerous and swift rapids on the way. Though Goudie had taken the precaution of having them dressed in army uniform to deter the enemy from attacking this did not prevent the occasional sniper from taking a shot. $^{58}$

Once in Kingston, the difficulties were of a different nature. Though the pay was good, when it was late and local merchants refused to give credit, the men, not unnaturally, struck, and they demanded also an increase in the rum ration. ${ }^{59}$ The problem of the difference in the wage scale of Goudie's and the other dockyard workers was more complicated to solve. ${ }^{60}$ When men left the yard, replacements were not immediately available, and work fell behind. ${ }^{61}$ And added to this, specialized workers, such as sailmakers, glaziers and blockmakers were almost impossible to find.$^{62}$ Apart from the personnel problems, the difficulties in obtaining the huge quantities of timber required on short notice, and in the transportation of

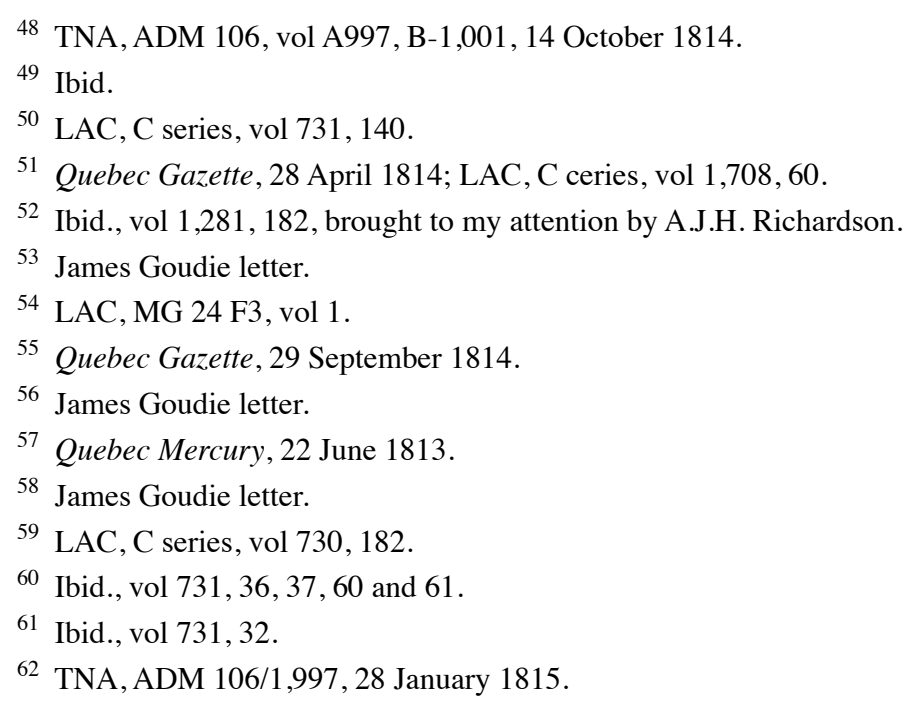


all other supplies from Montreal, tremendously complicated the whole operation.

The additional contracts that Goudie received in the winter of 1814-1815 for a seventy-four-gun ship to be built at Kingston, and two frigates, two brigs, one provision vessel and eleven gunboats to be built at the Ile-aux-Noix, Lake Champlain, ${ }^{63}$ speak for themselves. Goudie had proved his mettle. In January 1815, Goudie hired 234 men for the Kingston Dockyard and seventy-six for the Ile-aux-Noix. ${ }^{64}$ However, in March, the commissioner for the dockyards reported that the contracts had been dissolved, as the war had ended. Of all these vessels, only the gunboats were to be completed. Goudie received $£ 13,000$, one-third of the contract price. ${ }^{65}$

What might have been Goudie's final contribution to the War of 1812 was suddenly cut short. It is ironic that while Goudie was engaged in building up the Canadian navy at Kingston, his friend, Henry Eckford, was carrying out the same function for the Americans across the Lake, at Sackets Harbour.

When the war ended, Goudie was forty years old, and there was no holding him back. Always a man of action, he now took on a number of important projects with well-warranted self-confidence. He began by building a deep water wharf on St Peter Street, at St Antoine, in the lower town. He bought waterfront lots from John Mure and James Irvine late in $1815,{ }^{66}$ and that winter began giving out contracts for stone. ${ }^{67}$ The timber framer Michel Dulac undertook to build the wharf which was to be firmly anchored to solid rocks. Heavy timbers were to be dovetailed together to form cages, which were then to be sunk in place and filled with stone as the work proceeded. ${ }^{68}$ Many years later, James Goudie wrote of the "first deep water wharf in the City of Quebec."69

It was considered at that time a hazardous undertaking to build a deep water wharf on the St Lawrence beyond what is known as the bank, especially as the pressure of ice was menacing, but Goudie was not daunted by public opinion, which denounced the project as 'Goudie's Folly', ... the structure [continues James] has stood over sixty years with the necessary repairs. All the deep water wharves have been built since that time in this manner, hence he may be considered the investor and pioneer in this line of structural wharfage.

Known as Goudie's Wharf during his lifetime, by 1840, it had been given the name of its new owner James Gibb.

Even as the wharf was building, so also was the eighty-six-foot paddle steamer

\footnotetext{
63 TNA, ADM 106/1,997, 12 March 1815.

${ }^{64}$ ANQ, gr W.F. Scott, 12 and 15 January 1815.

${ }^{65}$ As 63.

${ }^{66}$ ANQ, gr J. Belanger, 9 October 1815, J.B. Plante, 11 Dec 1815.

${ }^{67}$ ANQ, gr J. Belanger, 7 February 1816(2).

${ }^{68}$ Ibid., 12 July 1816.

${ }^{69}$ Quebec Morning Chronicle, 1883.
} 
Lauzon, the first steamboat built for ferry service on the St Lawrence. A doubleender with a rudder each end, it was launched from Goudie's yard in 1817, ${ }^{70}$ and was registered in the names of John Goudie, John White, François Languedoc, John Caldwell and John Davidson of Quebec, and Hiram Nicholls of Montreal. ${ }^{71}$ An announcement in the Quebec Gazette advised prospective passengers that the Lauzon would leave Mr. Goudie's wharf at four o' clock every morning and continue plying until dark, stopping for a half-hour at each wharf. They were further assured that a sufficient number of canoes would provide the service in winter at the usual rates. The passengers could look forward to the completion within a few weeks of a large and commodious hotel close to the landing stage at Levis, with stables for 150 horses, where they would be comfortably accommodated. ${ }^{72}$ Goudie was true to his word, for Lady Aylmer later wrote at length of her enjoyment staying at the hotel, adding "we have nothing to complain of in the way of convenience." "73 The Lauzon is pictured on the $4 \mathrm{~d}$ lead tokens that were issued in 1821 to serve as tickets. $^{74}$

Only three other steamboats were built by Goudie at his yard; the 554 ton paddle steamer Quebec, of 1818, which joined the other steamboats on the Quebec Montreal run, ${ }^{75}$ and two small vessels, the fifty-two- ton Experiment and the twenty-nine-ton Flying Fish, both of $1823 .{ }^{76}$ In 1820 , however, Goudie bought shares in Torrance's steamboat Car of Commerce, ${ }^{77}$ and two years later he became a shareholder in the St Lawrence Steamboat Company, at which time His Quebec joined the Molson boats in the company's fleet. ${ }^{78}$ Although he had applied to the Legislature of the Province for the exclusive right to navigate one or more steamboats on Lake Champlain, within provincial waters, the plan does not seem to have been realized. ${ }^{79}$ Goudie's faith in the future of steam navigation is further demonstrated by the apprenticeship of his son, James, to the shipbuilder William Simons, of Greenock, in whose yard he acquired the knowledge of steamship construction that enabled him to return to Quebec to direct the construction of the Royal William. ${ }^{80}$

70 Quebec Gazette, 2 October 1817.

71 Reg Que 41/1817.

72 Quebec Mercury, 12 May 1818.

73 Cited by Christina Cameron \& Jean Trudel, The Drawings of James Cockburn: A Visit Through Quebec's Past ([Toronto]: Gage Publishing, [1976]), 51.

74 J.W. Miller, Bulletin des recherches historiques III, 1897, 109.

75 Private contract signed at Montreal, 27 April 1822, referred to in ANQ, gr L. McPherson, 8 July 1825 .

76 Reg Que 16/1823 and 18/1823.

77 ANQ, gr A. Campbell, 27 April 1820.

78 As 75.

79 Quebec Gazette, 9 November 1815 and 19 November 1818.

80 James Goudie to Archibald Campbell, 17 February 1891, letter in Appendix G, Report of the Secretary of State of Canada for the year ended 31 December 1894 , (Ottawa: Queen's Printer, 1895), 
Meanwhile, a rather special project had taken Goudie s attention. He formed a partnership in 1817 with four others two of whom were American citizens, to build and operate a diving bell. The five partners, under penalty of a $£ 1,000$ fine for non-compliance, agreed to keep the matter secret and to support the project for five years, whether it to be a losing or a profitable concern. The purpose of the bell was to clean the harbour of lost anchors. ${ }^{81}$ According to James Goudie, the work was finally abandoned for lack of experienced divers, after enjoying some success in removing lost anchors and chains. ${ }^{82}$

In 1818, Goudie opened the first steam-powered mill in Canada. Both a flour and a sawmill, it was run by a $48 \mathrm{hp}$ engine, had a large walking beam, a flywheel twenty-seven feet in diameter and a chimney over one hundred feet high. Its three large boilers were brought over from Glasgow on the deck of a ship, and caused some amazement when Goudie had them plugged up and floated round to his shipyard. Iron was then generally thought not to float. Engineers and workmen were brought over from Scotland with the machinery, to set it up. The flouring department had five pair of stones. There were four saw gates, each with a gang of twenty-two saws, and eight circular saws to make shingles and lath. ${ }^{83}$ The mill had the capacity to cut two hundred saw logs per day, and advertised planks, boards, scantling, flooring, laths, etc so true and clear that in applying them to house or any other use, they will at least save 25 percent of labour. A supply would be laid up under cover during the winter, so as to be well-seasoned the following spring. ${ }^{84}$ Saw logs were obtained from Upper Canada, and from many localities on either side of the river between Montreal and Quebec. ${ }^{85}$

Though the army wasted no time in giving Goudie contracts for various types of lumber, others were less pleased. Shipyard sawyers, who considered the steam sawmill a threat to their trade, made several attempts to burn it down. On 10 May 1819 , they succeeded. The loss in building, equipment and stock of materials was valued at over $£ 10,000{ }^{86}$ The following day, the Quebec Mercury denounced the cause that "checks the progress of that spirit of enterprize by which Mr. Goudie is so eminently distinguished." But Goudie's spirit of enterprise was not checked for long. He set to work rebuilding at once, and the following year opened an even larger mill ${ }^{87}$ In 1821 , he added two nail cutting machines to the equipment, hiring an operator who worked for one-third of the profits. ${ }^{88}$ The machine made nails

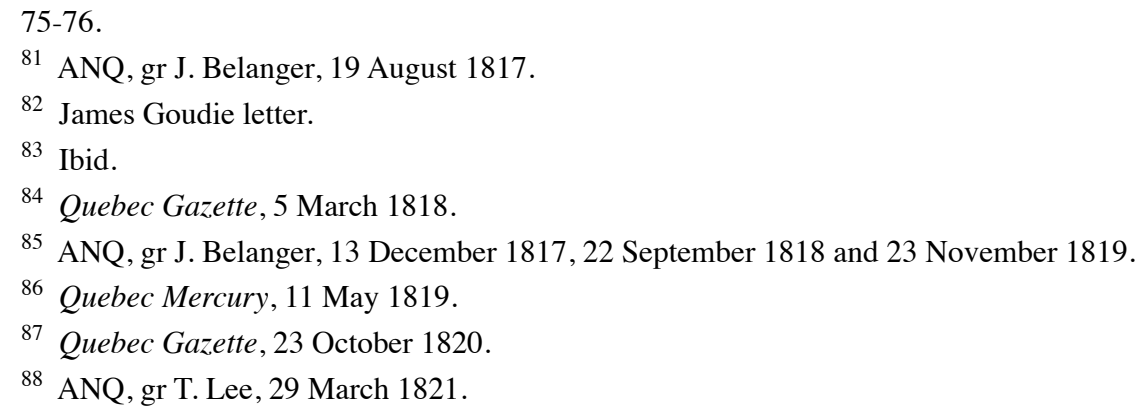


were much appreciated by carpenters, as they greatly cut down on the use of the gimlet. ${ }^{89}$ It took determination to keep the mill running. Not only were there the sawyers to contend with, but whenever the machinery broke down, the replacement parts had to be sent from Scotland, with a resulting delay of several months. ${ }^{90}$ It was perhaps as a back-up on those occasions, that Goudie bought a small water sawmill in Loretteville in $1819 .{ }^{91}$

Goudie's business ventures were not limited to those concerned with shipbuilding, shipping or milling. During the War of 1812, for instance, he prepared and leased three properties to the government for hospital, barrack use, etc ${ }^{92}$ and also did work to the line of telegraphs below the harbour of Quebec..$^{3}$ In 1817, he proposed and was one of seven signatories applying for the exclusive privilege of opening and maintaining a navigable canal, between St John's and Chambly Basin and from Chambly to the St Lawrence River, in the Parish of Longueil opposite Montreal. ${ }^{94}$ In 1821 , he contracted with the inspector of roads to make canals along St John Street and elsewhere in town. ${ }^{95}$ Also, in 1821 , he bought at auction the twenty-year lease on the King's Posts, which had previously been held by the North West Company, on behalf of four associates and himself. ${ }^{96}$ However, he is said to have referred to this partnership as the worst ship he ever sailed, as he had to meet all the expenses, ${ }^{97}$ and was no doubt relieved when James McDouall bought out all the partners and took over the lease in $1824 .{ }^{98}$ Goudie was a director of the Quebec Bank, ${ }^{99}$ and a shareholder in the Quebec Fire Insurance Company; ${ }^{100}$ he was appointed a member of Trinity House in $1820,{ }^{101}$ and a Justice of the Peace in $1822 .{ }^{102}$

Goudie had the dynamic qualities shared by many Scotsmen who left home to establish themselves in British North America, the West Indies or elsewhere in the Empire. They knew how to adapt, improvise and make the most of unfamiliar situations, and they made positive and practical contributions to their adopted

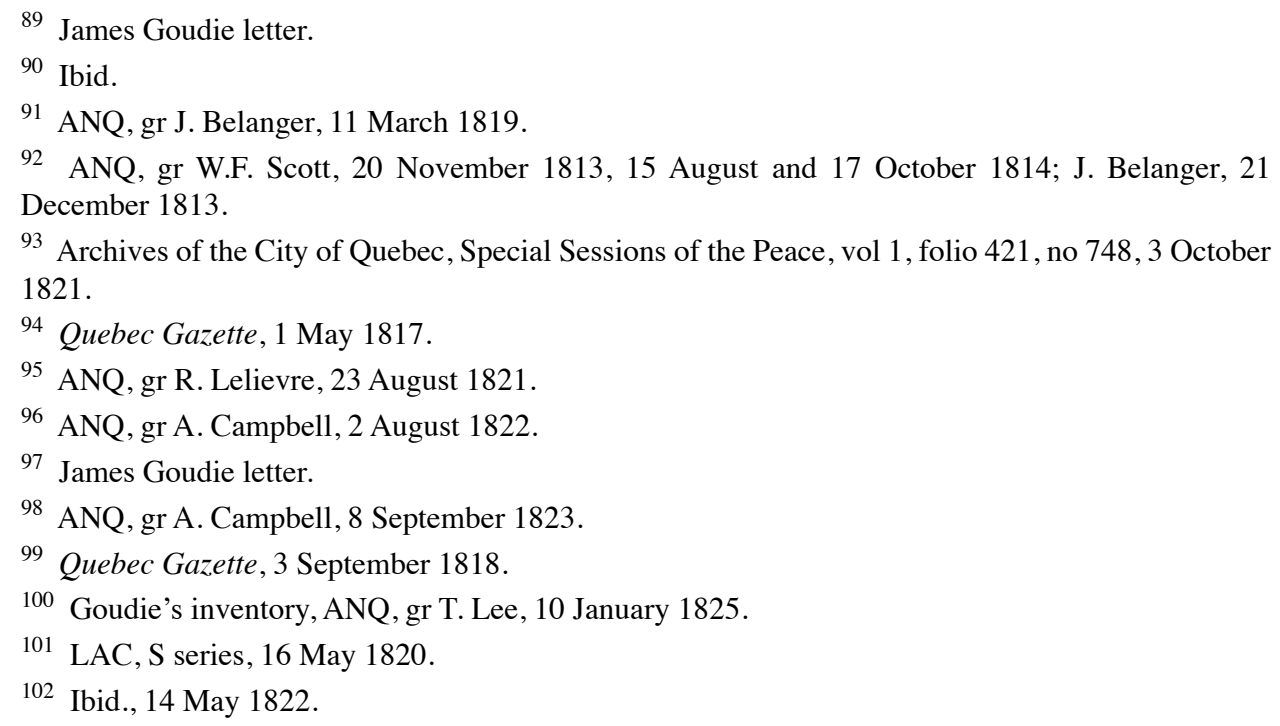


countries. Frequently, they enjoyed the financial backing of business associates in Scotland, who were often related, or related by marriage. John Goudie did not have that kind of backing. He stood squarely on his own two feet and was, as his son proudly wrote, a self-made man.

In shipping and other business deals, he followed the maxim that risks should be shared, particularly in the field of steamboat ownership, a relatively new field where accidents were frequent. His partners varied, but some such as François Languedoc and James McDouall were frequently associated with him. The steam sawmill, however, was his alone, and he seems to have held in his heart. In a poem written in 1821 by a young lady leaving Quebec, we find a simple yet eloquent farewell to the "sawmills, steam engine, dear of Mr. Goudie." 103

During the War of 1812, the see-saw war, the side with the largest vessel, held the upper position, and kept the enemy in port, until the situation was reversed by their launching an even larger one. ${ }^{104}$ Goudie overcame every difficulty and built those vital "larger" vessels. His great St Lawrence remained afloat at Kingston for many years, an inspiration to all Canadians. ${ }^{105}$

During his final years, the pulse of Quebec was changing. ${ }^{106}$ The Royal Engineers were hard at work building the Citadel on Cape Diamond. From his shipyard, he could watch Charles Wood's amazing vessels, the Columbus, and then the Baron of Renfrew taking shape. Goudie must have taken a great interest in both these projects, and will have found many opportunities to discuss and learn about the latest developments in shipbuilding and engineering in Britain. Were it not for his premature death, he would surely have introduced some of them to Quebec.

When he died in December 1824, the Quebec Mercury carried the following lines, the only contemporary comment we have on Goudie, the man: ${ }^{107}$

Mr. Goudie was distinguished for his great enterprising spirit, and for all the social virtues which he possessed in an eminent degree. He was highly useful to Government during the last war with the United States, by his activity and his skill in naval architecture, and was engaged to build several vessels of the largest size for His Majesty's service on the lakes. In him the Sovereign has lost a good and truly loyal subject his family a kind and tender relative and his friends a staunch supporter in the day of trouble.

\footnotetext{
1038 June.

104 Douglas, 24.

105 Preston, 11.

106 See A.J.H. Richardson, APT, Vol VI, 1974.

10718 December.
} 